\title{
Biodiesel dari Minyak Biji Kapuk Randu (Ceiba Pentandra) Menggunakan Katalis $\mathrm{Ca} / \mathrm{Hydrotalcite}$
}

\author{
Erlinda Ningsih ${ }^{1 *}$, Yustia Wulandari Mirzayanti' ${ }^{2}$, Achmad Chusnun Ni'am ${ }^{3)}$, Pipit \\ Febrianita $^{4}$ dan Wanvia Vangesti ${ }^{5}$ \\ 1,2,45)Jurusan Teknik Kimia, Fakultas Teknik, ITATS, Surabaya \\ 3)Jurusan Teknik Lingkungan, FTSP, ITATS, Surabaya \\ Jl. Arief Rahman Hakim no.100 Surabaya 60117 \\ Email : erlindaningsih84@itats.ac.id
}

\begin{abstract}
ABSTRAK
Ketersediaan bahan bakar berbahan baku fosil mengalami penurunan, sehingga diperlukan bahan bakar alternatif yang dapat memenuhi kebutuhan konsumen. Biodiesel merupakan bahan bakar alternatif dari biji-bijian yang memiliki peluang yang besar untuk dikembangkan. Salah satu biji yang dapat dimanfaatkan adalah biji kapuk randu. Tujuan dari penelitian ini adalah mengetahui pengaruh ratio molar minyak metanol dan penambahan katalis terhadap yield. Pembuatan biodiesel ini melalui empat tahapan yaitu preparasi katalis $\mathrm{Ca} /$ hydrotalcite, degumming. Esterifikasi dan transesterifikasi. Minyak kapuk randu yang sudah dihilangkan gum dan diturunkan kadar FFA di bawah 1\%, kemudian minyak tersebut diproses transesterifikasi dengan penambahan katalis yang sudah dipreparasi $(0,5 \%, 1 \%$ dan $1,5 \% \mathrm{w} / \mathrm{w}$ dari massa minyak). Berdasarkan penelitian didapatkan pada rasio molar 1 minyak : 20 metanol menghasilkan kadar FAME tertinggi sebesar 5,55\% dan yield biodiesel yang dihasilkan adalah $3,92 \%$.
\end{abstract}

Kata kunci : biodiesel; kapuk; Ca; hydrotalcite; katalis

\begin{abstract}
The availability of fossil-based fuels has decreased, so that alternative fuels are needed that can meet consumer needs. Biodiesel is an alternative fuel from seeds that has a great opportunity to be developed. One of the seeds that can be utilized is kapok randu seeds. The purpose of this study was to determine the effect of methanol molar ratio and the addition of catalysts to yield. Making this biodiesel through four stages, namely preparation of $\mathrm{Ca} /$ bydrotalcite catalyst, degumming. Esterification and transesterification. The kapok randu oil that has been removed by gum and reduced FF $A$ levels below 1\%, then the oil is processed transesterification by adding a prepared catalyst $(0.5 \%, 1 \%$ and $1.5 \% \mathrm{w} / \mathrm{w}$ of oil mass). Based on the research, it was found that the molar ratio of 1 oil: 20 methanol produced the highest FAME content of 5.55\% and the yield of biodiesel produced was $3.92 \%$.
\end{abstract}

Keywords : biodiesel; kapok; Ca; hydrotalcite; catalyst 


\section{PENDAHULUAN}

Pertumbuhan penduduk di Indonesia setiap tahun semakin meningkat. Peningkatan ini berpengaruh pada jumlah kebutuhan konsumen akan energi. Sedangkan cadangan energi yang berasal dari fosil mulai menipis. Oleh karena itu perlu dilakukan upaya untuk mengatasi hal tersebut misalnya dengan melakukan penghematan dan mencari sumber energi yang dapat diperbaharui serta ramah lingkungan.

Biodiesel merupakan salah satu energi alternatif, karena bahan bakunya berasal dari minyak nabati atau lemak hewani yang memiliki sifat menyerupai minyak diesel atau solar. Biodiesel digolongkan sebagai bahan bakar yang dapat diperbarui [1]. Keunggulan biodiesel dibandingkan bahan bakar konvensional antara lain sifatnya yang dapat diperbaharui (Renewable), tidak beracun dan terurai secara alami (Biodegradable) [2]. Dalam sektor lingkungan, biodiesel memiliki kelebihan karena dapat mengurangi emisi $\mathrm{SOx}, \mathrm{NOx}$, dan $\mathrm{CO}_{2}$ yang merupakan gas-gas penyumbang pemanasan global.

Kapuk randu (Ceiba Pentandra) merupakan salah satu tanaman yang berpotensi menghasilkan minyak. Minyak biji kapuk berwarna kuning jernih yang mengandung asam lemak tidak jenuh sekitar $71,95 \%$, lebih tinggi dibandingkan dengan minyak kelapa. Hal ini menyebabkan minyak biji kapuk mudah tengik, sehingga kurang baik untuk dikembangkan sebagai minyak makanan. Namun minyak biji kapuk berpotensi untuk dijadikan substitusi minyak diesel.

Pada umumnya, biodiesel diproduksi melalui reaksi transesterifikasi. Namun kandungan asam lemak bebas (FFA) dari minyak biji kapuk yang tinggi, maka diperlukan proses esterifikasi terlebih dahulu sebelum dilakukan proses transesterifikasi. Pada proses transesterifikasi menggunakan katalis pada reaksinya. Pada umumnya katalis mempengaruhi arah atau selektivitas reaksi. Katalis mampu meningkatkan kecepatan reaksi sampai kurang lebih $10^{11}$ kali lipat .Tanpa adanya katalis, konversi yang dihasilkan maksimum namun reaksi berjalan dengan lambat [3]. Katalis yang biasa digunakan yaitu katalis basa karena katalis ini dapat mempercepat reaksi.

Pada penelitian ini digunakan katalis heterogen. Secara umum, katalis heterogen berbentuk padat dan banyak digunakan pada reaktan berwujud cair maupun gas. Katalis lebih mudah dipisahkan dari produk reaksi dengan cara filtrasi dan tidak memerlukan air untuk proses pencucian serta dapat digunakan kembali [4][5]. Katalis heterogen ini tidak korosif, memiliki umur katalis yang lebih lama, selektifitas dan aktifitas tinggi [6]. Kalsium karbonat merupakan katalis heterogen yang paling diminati, karena memiliki kelarutan yang rendah di dalam minyak/lemak dan dapat diperoleh dengan harga murah serta memiliki struktur yang lebih besar sehingga mudah dalam proses pemisahannya.

$$
\text { Hydrotalcite }\left[\mathrm{Mg}_{6} \mathrm{Al}_{2}(\mathrm{OH})_{16}\right]^{2+} \mathrm{CO}_{3}{ }^{2-} \cdot 4 \mathrm{H}_{2} \mathrm{O}
$$
telah banyak dikembangkan karena memiliki potensi yang baik sebagai adsorben [8] dan sebagai katalis [9]. Hydrotalcite sebagai katalis mempunyai beberapa keuntungan proses penangananya mudah, mudah dipisahkan dengan produk, ramah lingkungan dan menghasilkan produk yang bagus.

Berdasarkan pemaparan penelitian sebelumnya, maka penelitian ini memanfaatkan minyak biji randu sebagai bahan baku biodiesel dengan menggunakan katalis heterogen yaitu $\mathrm{Ca} /$ Hydrotalcite untuk mendapatkan biodiesel yang sesuai dengan standart dan ramah lingkungan. 


\section{METODE PENELITIAN}

Peralatan yang digunakan dalam penelitian ini yaitu seperangkat alat kalsinasi dan seperangkat alat transesterifikasi pada reaktor batch. Bahan-bahan yang digunakan adalah minyak biji kapuk didapat dari Pasuruan Jawa Timur, Metanol 92\%, $\mathrm{H}_{3} \mathrm{PO}_{4}$, $\mathrm{H}_{2} \mathrm{SO}_{4}$, Hydrotalcite dan $\mathrm{CaCO}_{3}$.

\section{Prosedur Kerja}

\section{Preparasi Katalis $\mathrm{Ca} / \mathrm{Hydrotalcite}$}

Bahan yang digunakan yaitu $\mathrm{CaCO}_{3}$ dan Hydrotalcite yang telah dikeringkan selama 12 jam dengan suhu $110^{\circ} \mathrm{C}$. Pada awal proses bydrotalcite dikalisinasi terlebih dahulu selama 5 jam pada suhu $650^{\circ} \mathrm{C}$. Pada penelitian ini dilakukan metode Incipient Wetness Impregnation (impregnasi basah) Hydrotalcite dengan cara dispray secara bertahap dengan larutan $\mathrm{CaCO}_{3} . \%$ Loading logam Ca yang digunakan adalah 2,5\% terhadap Hydrotalcite. Dilanjutkan pengadukan selama 30 menit dan pengeringan dalam oven pada suhu $110^{\circ} \mathrm{C}$ selama 12 jam. Selanjutnya dilakukan proses kalsinasi dengan suhu operasi $550^{\circ} \mathrm{C}$ selama 2 jam dan suhu reduksi dengan $\mathrm{H}_{2}$ pada $450^{\circ} \mathrm{C}$ selama 3 jam.

\section{Degumming}

Degumming merupakan proses pemisahan pengotor minyak seperti getah (gum) atau lendir-lendir yang terdiri dari fosfatida, protein, residu, karbohidrat, air, dan resin. Proses degumming dilakukan dengan memanaskan minyak dengan suhu $70^{\circ} \mathrm{C}$ dan di tambahkan larutan $\mathrm{H}_{3} \mathrm{PO}_{4}$ sebesar $0,1 \%$ dari volume minyak. Proses ini dilakukan dengan suhu konstan $70^{\circ} \mathrm{C}$ selama 30 menit [10].

\section{Esterifikasi}

Esterifikasi bertujuan untuk menurunkan kadar asam lemak bebas (Free Fatty Acid) pada minyak. Esterifikasi dilakukan dengan cara mereaksikan minyak biji kapuk dan metanol dengan perbandingan rasio molar minyak dan metanol sebesar 1:6. Suhu operasi esterifikasi $60^{\circ} \mathrm{C}$ selama 1,5 jam dengan menambahkan katalis asam. Katalis asam yang digunakan pada penelitian ini adalah $\mathrm{H}_{2} \mathrm{SO}_{4}$ sebanyak $1 \%$ dari massa minyak.

Gambar 1. Rangkaian Peralatan Kalsinasi

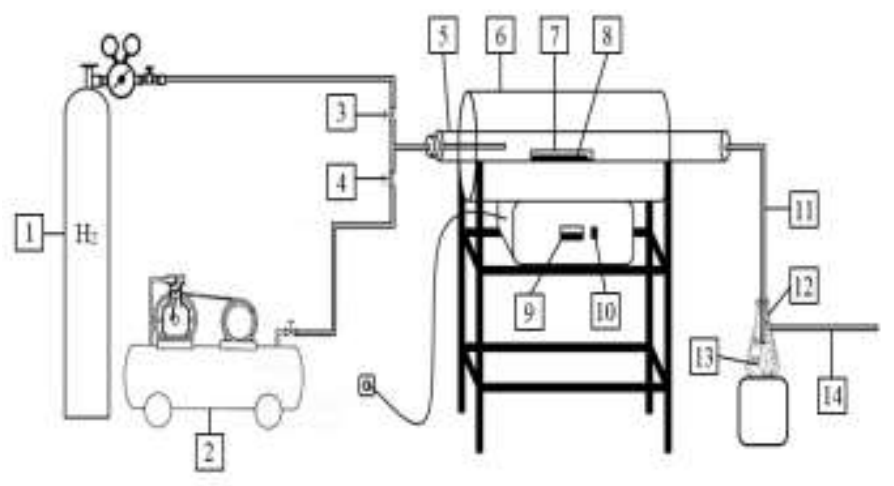

Keterangan Gambar 1 :

1. Tabung gas $\mathrm{H}_{2}$

2. Kompresor

3. Valve tube gas $\mathrm{H}_{2}$

4. Tube valve udara

5. Reaktor kalsinasi

6. Furnace

7. Nucelle

8. Katalis

9. Panel kontrol suhu furnace

10. Tombol power

11. Gas outlet tube reaktor kalsinasi

12. Erlenmeyer

13. Air

14. Gas outlet tube Erlenmeyer

\section{Transesterifikasi}

Transesterifikasi dilakukan dengan mereaksikan minyak dan methanol dengan molar ratio 1:10, 1:15 dan 1:20. Variabel jumlah katalis $\mathrm{Ca} / \mathrm{Hydrotalcite}$ yang ditambahkan sebesar $0,5 \%, 1 \%$ dan $1,5 \% \mathrm{w} / \mathrm{w}$ dari massa minyak. Proses transesterifikasi dilakukan pada kondisi operasi $65^{\circ} \mathrm{C}$ selama 120 menit. 


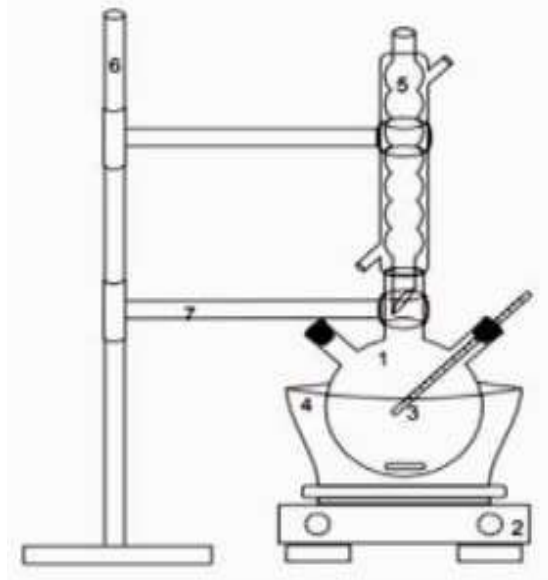

Keterangan Gambar 2 :

1. Labu leher tiga

2. Magnetic Stirrer + pemanas

3. Termometer

4. Waterbath

5. Kondenser refluk

6. Statif Klem

Gambar 2. Rangkaian Peralatan

Transesterifikasi

\section{HASIL DAN PEMBAHASAN}

\subsection{Komposisi Minyak biji Kapuk}

Untuk mengetahui komposisi asam lemak yang terkandung pada minyak biji kapuk dilakukan analisa GC-MS.

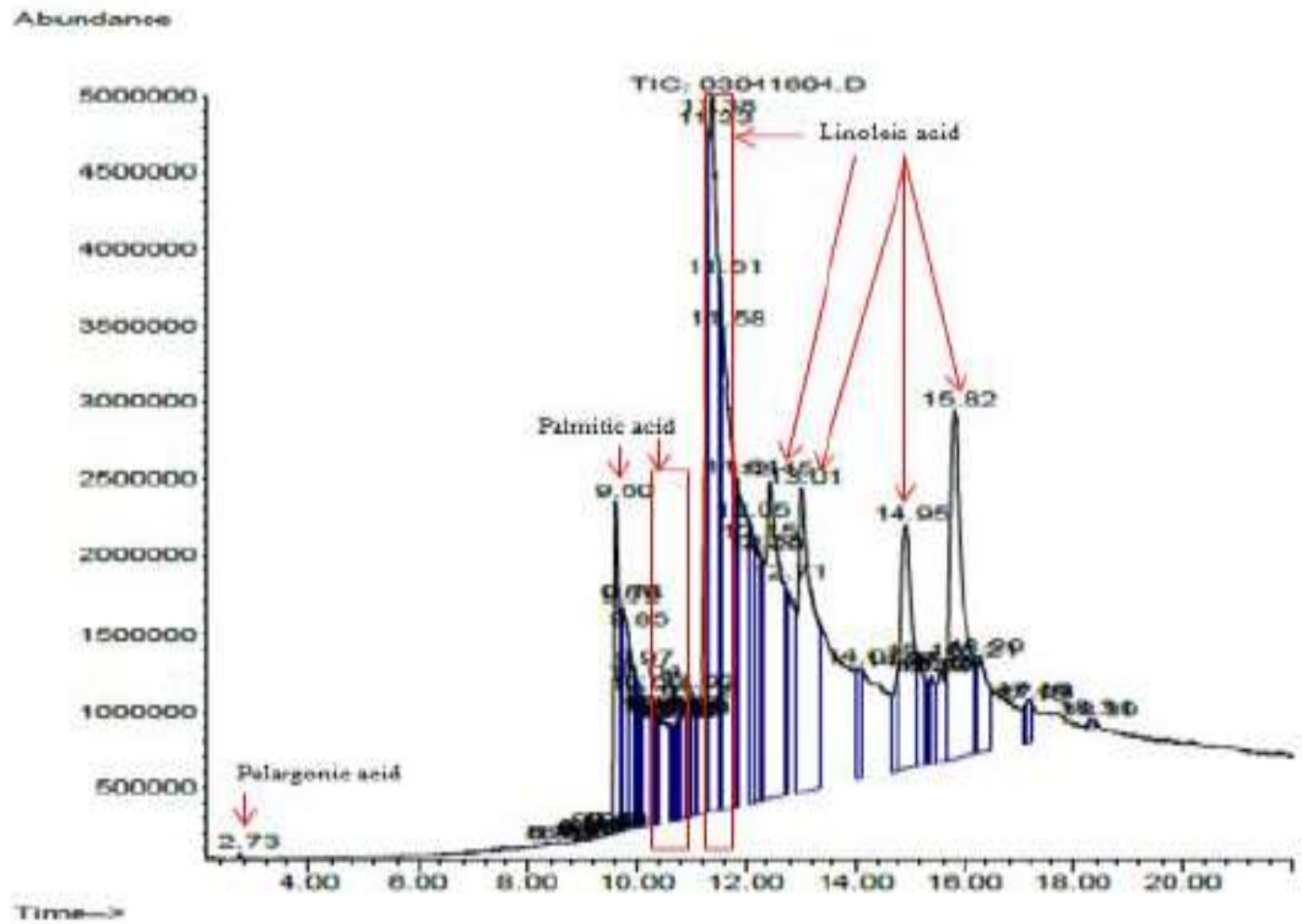

Gambar 3. Hasil Analisa GC-MS pada Minyak Biji Kapuk

Gambar 3 menunjukkan bahwa peak paling tinggi yaitu pada retention time 11,38 menit dan peak tertinggi kedua pada retention time 11,33 menit dimiliki oleh senyawa Linoleic acid. Hasil pembacaan menggunakan GCMS dapat dilihat pada Tabel 1. 
Bedasarkan Tabel 1 dapat dijelaskan bahwa komposisi kandungan yang paling banyak pada minyak biji kapuk adalah asam linoleat dengan persentase 78,85\%. Kandungan komposisi terbanyak kedua yaitu asam palmitat sebesar 21,12\%. Dan kandungan asam pelargonic sebesar $0,03 \%$.

Tabel 1. Komposisi Asam Lemak pada Minyak Biji Kapuk

\begin{tabular}{cccc}
\hline $\begin{array}{c}\text { Komposisi } \\
\text { Asam }\end{array}$ & $\begin{array}{c}\text { Rumus } \\
\text { Molekul }\end{array}$ & BM & $\begin{array}{c}\text { Komposisi } \\
\text { (\% berat) }\end{array}$ \\
\hline $\begin{array}{c}\text { Asam Linoleat } \\
(\mathrm{C} 18: 2)\end{array}$ & $\mathrm{C}_{18} \mathrm{H}_{32} \mathrm{O}_{2}$ & 280 & 78,85 \\
$\begin{array}{c}\text { Asam Palmitat } \\
(\mathrm{C} 16)\end{array}$ & $\mathrm{C}_{16} \mathrm{H}_{32} \mathrm{O}_{2}$ & 256 & 21,12 \\
AsamPelargonic & $\mathrm{C}_{9} \mathrm{H}_{18} \mathrm{O}_{2}$ & 158 & 0,03 \\
\hline \multicolumn{2}{c}{ Total } & & 100 \\
\hline
\end{tabular}

\section{Yield Biodiesel}

Tabel 2. Hasil Uji kadar FAME

\begin{tabular}{lllll}
\hline No & Rasio Molar & \multicolumn{3}{c}{ Kadar FAME (\%) } \\
\hline & $\begin{array}{l}\text { Minyak } \\
\text { Metanol }\end{array}$ & $:$ & \multicolumn{3}{c}{ Massa Katalis } \\
\hline & & 0,5 & 1 & 1,5 \\
\hline 1 & $1: 10$ & - & - & 5,43 \\
\hline 2 & $1: 15$ & - & 1,75 & - \\
\hline 3 & $1: 20$ & 3,66 & 5,55 & - \\
\hline
\end{tabular}

Dari Tabel 2 hasil uji kadar FAME dan yield biodiesel dengan variasi massa katalis $\mathrm{Ca} /$ Hydrotalcite dan perbedaan rasio molar minyak : metanol dengan suhu transesterifikasi $60^{\circ} \mathrm{C}$ dapat diketahui kadar FAME tertinggi dengan massa katalis $1 \%$ dan rasio molar 1:20 yaitu 5,55\%. Sedangkan dengan massa katalis yang sama yaitu $1 \%$ dan rasio molar yang sama 1:15 didapatkan kadar FAME terkecil yaitu $1,75 \%$.

Gambar 4 menunjukkan bahwa grafik pengaruh massa katalis dan rasio molar minyak : methanol terhadap yield biodiesel, berdasarkan grafik tersebut penggunaan massa katalis 1,5\% dan rasio molar 1:10 diperoleh yield sebesar 3,53\%. Pada penggunaan massa katalis $0,5 \%$ dan rasio molar 1:20 diperoleh yield sebesar 2,92\%. Pada penggunaan massa katalis $1 \%$ dan rasio molar 1:20 diperoleh yield tertinggi sebesar $3,92 \%$.

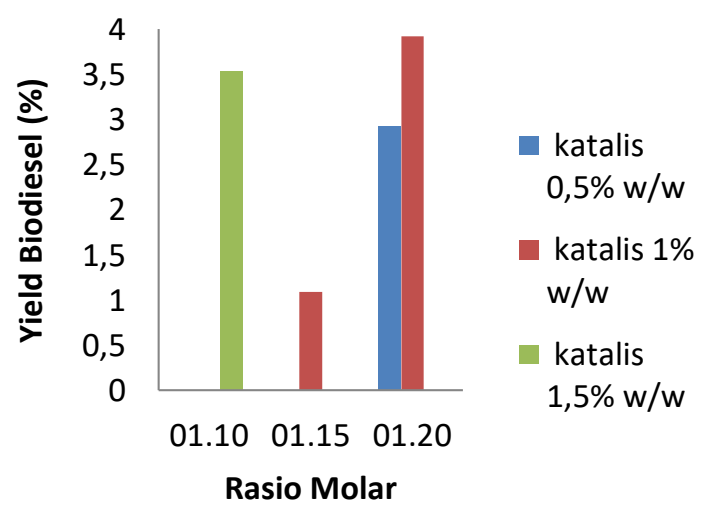

Gambar 4. Grafik Pengaruh Massa Katalis dan Rasio Molar Minyak : Metanol terhadap Yield Biodiesel

Sedangkan dengan penambahan katalis 1\% dengan rasio molar 1:15 diperoleh yield terkecil yaitu 1,09\%. Kenaikan \% yield biodiesel pada produk mengindikasikan bahwa katalis $\mathrm{Ca} /$ Hydrotalcite berperan dalam reaksi dan memberikan kenaikan \% yield biodiesel tertinggi dengan penambahan katalis 1\%. Dari uji XRD kristalinitas katalis $\mathrm{Ca} /$ Hydrotalcite menunjukkan peak yang rendah dan lebar sehingga katalis $\mathrm{Ca} /$ Hydrotalcite lebih bersifat amorf (kadarnya rendah). Dan uji BET luas permukaan katalis $\mathrm{Ca} /$ Hydrotalcite yang diperoleh $<100 \mathrm{~m}^{2} / \mathrm{g}$ sehingga luas kontak reaktan dengan katalis belum memberikan hasil yang maksimal. Pada penelitian ini suhu kalsinasi masih tergolong rendah yaitu $550^{\circ} \mathrm{C}$ dimana $\mathrm{CaCO}_{3}$ yang terdapat didalam sampel belum berubah menjadi $\mathrm{CaO}$. Adanya $\mathrm{CaCO}_{3}$ dalam $\mathrm{CaO}$ dapat menyebabkan aktivitas katalis menurun.

Aktivitas katalis berpengaruh terhadap yield yang dihasilkan pada reaksi transesterifikasi. Pada suhu kalsinasi $550^{\circ} \mathrm{C}$ 
yield tertinggi yang dihasilkan hanya 3,92\%. Hasil tersebut sesuai dengan laporan [11], bahwa kalsium oksida yang dikalsinasi pada suhu dibawah $550^{\circ} \mathrm{C}$, jika digunakan sebagai katalis pada reaksi transesterifikasi akan menghasilkan yield rendah. Masih adanya asam lemak bebas sisa yang tidak bereaksi cenderung menghambat pembentukan produk (metil ester) sehingga hasil kadar FAME yang didapat kecil. Pengaruh penggunaan metanol dalam jumlah yang berlebih dapat menyebabkan reaksi cenderung ke arah produk sehingga konversi FAME semakin besar dan yield yang diperoleh pun semakin besar.

\section{KESIMPULAN}

1. Biodiesel terbaik didapatkan pada kondisi penambahan massa katalis $\mathrm{Ca} /$ Hydrotalcite $1 \% \mathrm{w} / \mathrm{w}$ berbasis minyak biji kapuk dan rasio molar minyak 1:20 metanol.

2. Pada rasio molar 1 minyak : 20 metanol menghasilkan kadar FAME tertinggi sebesar 5,55\% dan yield biodiesel yang dihasilkan adalah 3,92\%.

3. Konversi FFA terbaik didapatkan pada kondisi penambahan massa katalis $\mathrm{Ca} /$ Hydrotalcite $1 \% \mathrm{w} / \mathrm{w}$ berbasis minyak biji kapuk dan rasio molar 1 minyak : 20 metanol yaitu $91,88 \%$.

\section{PENGHARGAAN}

Peneliti mengucapkan terima kasih kepada Ristek Dikti DRPM 2018

\section{DAFTAR PUSTAKA}

[1] Knothe G, Gerpen J.V., Krahl J. 2005. The Biodiesel handbook. AOCS Press.

[2] Pratama, L., Yoeswono.,Triyono., dan Tahir, I. 2009. Effect of temperature and speed of stirrer to biodiesel conversion from coconut oil with the use of palm empty fruit bunches as a beterogeneous catalyst. Indonesian Journal of Chemistry, 9 (1): 54-61.

[3] Hasahatan, Dennis., Sunaryo, Joko., Komariah L.N. 2012. Pengarub Ratio H2SO4 dan Waktu Reaksi Terhadap Kuantitas dan Kualitas Biodiesel dari Minyak. Jarak Pagar. Jurusan Teknik Kimia Fakultas Teknik Universitas Sriwijaya.

[4] Bala, D.D., Souza, K.D., Misra, M., Chidambaram, D., Conversion of a variety of high free fatty acid containing feedstock to biodiesel using solid acid supported catalyst, Journal of Cleaner Production 104 (2015) 273-281.

[5] Janaun, J., Ellis, N., Perspectives on biodiesel as a sustainable fuel. Renewable and Sustainable Energy Reviews 2010; 14: 1312-20.

[6] Liu., X., He. H, Wang, Y. Zhu, S. Piao, X.2008. Transesterifikasi of soybean oilto biodiesel using $\mathrm{CaO}$ as a solid base catalyst. Elvisier fuel. (87) : hal.216-221

[8] Wright, J., 2002, Removal of Organic Colours from Raw Water Using Hydrotalcite, University of Queensland, Brisbane.

[9] Kishore, D., Kannan, S. 2004. Environmentally Begin Route for Isomerization of Safrole-Hydrotalcite as Solid Base Catalyst. Journal of Molecular Catalyst A : Chemical, 223,225-230.

[10] Suryandari, A.S., Prasasti, S.N., Roesyadi, A., (2013), Pembuatan Biodiesel dari Minyake Biji Kapuk (Ceiba Petandra) Melalui Proses Transesterifikasi dengan Katalis $\mathrm{MgO} / \mathrm{CaO}$. Jurnal Teknik Pomits vol. 2. ITS

[11] Fujita S. Ichiro., Bhanage B. M., Kanamaru H., Arai M. (2005) Synthesis of 1,3 - dialkylurea from ethylene carbonate and amine using calcium oxide. Journal Transactions of the ASAE, 1203-1210 